\title{
Export Dynamism and Market Access
}

\author{
Jörg Mayer \\ United Nations Conference on Trade and Development
}

\begin{abstract}
Market access liberalization has influenced product-specific growth of world exports and contributed to the shift in the structure of world exports of manufactures towards electrical and electronic goods (including parts and components), goods that require high $R \& D$ expenditures, and labour-intensive products such as clothing. Multilateral trade liberalization has strongly improved market access conditions for manufactures and partly explains why manufactures have experienced particularly strong growth in exports. The increased importance of vertical international production sharing and the associated preferential trading arrangements between geographically close countries with significantly different wage rates have been a key determinant of differences in export-value growth across individual manufactured products, as well as of the distribution of market shares for some of these products among developing countries. Projections based on a standard trade model suggest that moving to full trade liberalization would lead to an increase in the share of agricultural products in total world trade by almost two percentage points and give greater weight to the textile, clothing and automotive sectors within manufactured exports.
\end{abstract}

- JEL Classifications: F10, F13, F14, F17, O20

- Key words: Trade flows, Trade liberalization, International production networks, Development policy

\section{Introduction}

The rate of growth in the value of international trade has been strong and since

\footnotetext{
*Corresponding address: Jörg Mayer, UNCTAD, Palais des Nations, CH-1211 Geneva 10, Tel: 41-229075722, Fax: 41-22-917-0274, E-mail: joerg.mayer@unctad.org

(C)2004-Center for International Economics, Sejong Institution, All Rights Reserved.
} 
the mid-1980s has consistently exceeded that of world output. This has been accompanied by a growing participation of developing countries in world trade over the past three decades between - 1970 and 2000, the share of developing countries in global merchandise trade rose from about one-fourth to almost onethird - and by a rapid transformation in the composition of their exports from primary commodities to manufactures, particularly since the early 1980s: manufactures now account for 70 per cent of developing country exports, after stagnating at around 20 per cent in the 1970s and early 1980s.

Feenstra (1998) suggests four possible factors to explain the growth of world trade: trade liberalization, falling transportation costs, income convergence among the main trading economies, and increased vertical international production sharing. Several empirical studies have tried to disentangle the relative importance of these factors. Concentrating on the growth in trade relative to income among a group of 16 developed countries, and hence not considering the impact of vertical international production sharing, Baier and Bergstrand (2001: 21), for example, conclude that "trade liberalisation appears to have contributed about $75 \%$ of the (approximately) 2\% annual growth of world merchandise trade as a share of income in the post-war period compared with transport-cost declines, which have contributed only $25 \%$ of the growth in trade relative to income".

A common characteristic of these empirical studies is that they examine trade on the basis of the gravity model, which relates bilateral trade to national income, population, geographic distance, and an array of dummy variables reflecting the presence or absence of a preferential trading agreement or of a common land border. As explained by Baier and Bergstrand (2001: 4), the theoretical basis of the gravity equation is a reduced form from a general equilibrium model of international trade in final goods. This would imply that the approach cannot be readily applied to analyse product-specific growth because, as will be shown, growth in international trade has been driven to an important extent by trade in intermediate products, such as parts and components, rather than by trade in final goods. Fink et al. (2002) use a modified gravity equation to examine the quantitative effect of geographical distance, tariffs, and communication costs on sector-specific bilateral trade (at the 2-digit SITC level) among 107 countries in 1999. Focusing on the relative importance of tariffs and communication costs in determining bilateral trade, the evidence suggests wide variation across sectors with the impact of tariff barriers being comparatively high in those sectors that, following Yeats (2001) and $\mathrm{Ng}$ and Yeats (2001), include a significant level of 
trade in parts and components. Fink et al. (2002) employ importer- and exporterspecific dummy variables to account for country-specific determinants, such as income levels and consumption patterns. However, recent work on economic geography has shown that market segmentation, such as that associated with vertical international production sharing, leads to an intimate interaction between demand and production patterns. This interaction is particularly important in a dynamic context that seeks to examine the geographic relocation of industrial production or changes in consumption patterns as income rises, and the ensuing growth of trade over time. Departing from the assumption of a given level of production or a given pattern of consumption in order to examine growth of sector-specific trade over time would lead to a significant complication of the empirical model used in Fink et al. (2002). This is beyond the scope of this paper but could be an interesting area of future research.

Yi (2003) proposes a different route to track the impact of tariff reductions on trade growth. He argues that standard models of trade in final goods cannot account for how the observed decline in trade barriers could have produced the dramatic growth in world trade. Yi (2003) shows theoretically how vertical specialization allows a decline in trade barriers to trigger magnified and non-linear decreases in production costs and thus dramatic increases in world trade flows and calibrates his model to trade between the United States (US) on the one hand and the other developed countries taken as a group on the other hand for the period 1962 - 99. While his model performs much better than a standard trade model, it still leaves half of trade growth unexplained. Moreover, calibrating the model requires data that are not available either at a product-specific level or for a sufficiently large number of countries that would allow applying Yi's (2003) model for the purposes of this paper.

Given the absence of a suitable empirical model, this paper uses statistical evidence to provide a first step towards a comprehensive product-specific examination of the factors that have driven the evolution of world trade at the 3-digit Standard International Trade Classification (SITC) level of aggregation over the past two decades. Following Baier and Bergstrand (2001), Fink et al. (2002) and Yi (2003), the paper concentrates on trade liberalization. The past few decades have witnessed a decline in market access barriers due to both the conclusion of successive rounds of multilateral trade negotiations and a wave of unilateral reforms. The Uruguay Round agreements have led to improvements particularly for industrial products and helped to reduce the average tariffs on manufactures in both developed and 
developing countries to about half their levels in the early 1980s. In addition to multilateral and unilateral trade reform, the paper also examines the impact of bilateral and regional trade liberalization. The development of international production sharing has often been associated with the provision of preferential market access for geographically close neighbours with significantly different wage rates. Given the discriminatory nature of preferential trading agreements, their growing importance over the past few years is likely to have influenced both product-specific growth in world exports and the distribution of market shares among developing countries.

The paper is organized as follows. It starts by examining product-specific differences in value growth of world exports at the 3-digit SITC level over the period $1980-2000$ (section 2). It then looks at changing market access conditions to see to what extent product-specific differences in market-access liberalization are associated with product-specific differences in export dynamism: section 3 looks at market-access liberalization in the multilateral trading system and by way of case studies examines the correlation between product-specific changes in effectively applied tariffs of world imports and product-specific dynamism in the exports of Brazil, India, the Republic of Korea, and Mexico for the period 1995 2000; section 4 examines the implications of commercial policies for the formation of international production networks and the extent to which preferential trading arrangements between developed and developing countries, which are often associated with international production networks, have influenced the distribution of market shares among developing countries; section 5 examines potential changes in product-specific shares in world exports that would arise from moving towards global free trade. Section 6 concludes.

\section{Dynamic products in world trade ${ }^{1}$}

During the past two decades, the value of world merchandise exports ${ }^{2}$ has grown at an average rate of more than 8 per cent per annum. However, there have

\footnotetext{
'This section builds on Mayer et al. (2003) and UNCTAD (2002: Chapter 3).

${ }^{2}$ The analysis of market dynamism of products is concerned with export earnings rather than export volumes, since, for most products, separate volume and price data are not available. However, readily available evidence suggests that ranking of products would remain largely unchanged if growth rates of products in world exports could be calculated on the basis of constant rather than current prices; see UNCTAD (2002: Chapter 3, Annex 2).
} 
been considerable differences in the growth rates of trade of individual products. Among the 225 products at the 3-digit level of the Standard International Trade Classification (SITC) covered by this paper, some grew at rates twice as fast as the average growth in world trade, whereas for a large number of primary commodities, as well as some manufactures exports values registered sluggish or negative growth rates.

Various measures ${ }^{3}$ can be used to define the dynamism of a specific products evolution in global exports over time, including the rate of growth over alternative periods, the degree of growth stability, and changes of a products share in total exports. Table 1 shows the trend growth rates for the period $1980-2000$ of the 20

\section{Table 1}

Export value growth and share in total exports of the 20 most dynamic products, $1980-2000$

\begin{tabular}{|c|c|c|c|c|c|c|c|}
\hline \multirow[t]{3}{*}{$\begin{array}{l}\text { SITC } \\
\text { code }\end{array}$} & \multirow[t]{3}{*}{ Product group } & \multirow{2}{*}{\multicolumn{2}{|c|}{ 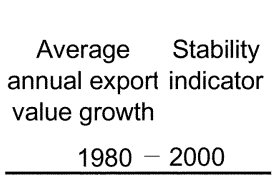 }} & \multicolumn{2}{|c|}{$\begin{array}{l}\text { Share in } \\
\text { world } \\
\text { non-fuel } \\
\text { exports }\end{array}$} & \multicolumn{2}{|c|}{$\begin{array}{l}\text { Share in non-fuel } \\
\text { exports from } \\
\text { developing } \\
\text { countries }\end{array}$} \\
\hline & & & & 1980 & 2000 & 1980 & 2000 \\
\hline & & \multicolumn{2}{|l|}{ (per cent) } & \multicolumn{2}{|c|}{ (per cent) } & \multicolumn{2}{|c|}{ (per cent) } \\
\hline 776 & Transistors and semiconductors & 17.4 & 0.99 & 1.0 & 4.1 & 1.9 & 7.8 \\
\hline 871 & Optical instruments & 16.1 & 0.98 & 0.1 & 0.3 & 0.0 & 0.3 \\
\hline 752 & Computers and units thereof & 15.3 & 0.97 & 0.9 & 3.4 & 0.2 & 5.1 \\
\hline 759 & Parts of computers and office machines & 15.2 & 0.98 & 0.7 & 2.4 & 0.3 & 3.9 \\
\hline 846 & Knitted undergarments & 13.4 & 0.96 & 0.3 & 0.6 & 0.8 & 1.5 \\
\hline 771 & Electric power machinery & 13.4 & 0.98 & 0.3 & 0.6 & 0.2 & 0.9 \\
\hline 553 & Perfumery and cosmetics & 13.4 & 0.96 & 0.2 & 0.5 & 0.1 & 0.2 \\
\hline 893 & Plastic articles & 13.1 & 0.95 & 0.6 & 1.2 & 0.6 & 1.1 \\
\hline 764 & Telecom equipment, and parts & 12.8 & 0.99 & 1.5 & 3.0 & 1.7 & 2.9 \\
\hline 773 & Electricity distributing equipment & 12.3 & 0.96 & 0.4 & 0.7 & 0.3 & 1.0 \\
\hline 872 & Medical instruments and appliances & 12.3 & 0.98 & 0.2 & 0.4 & 0.1 & 0.2 \\
\hline 898 & Musical instruments and records & 12.3 & 0.95 & 0.3 & 0.7 & 0.2 & 0.5 \\
\hline 111 & Non-alcoholic beverages & 12.2 & 0.93 & 0.1 & 0.1 & 0.1 & 0.1 \\
\hline 541 & Medicinal and pharmaceutical prod. & 12.2 & 0.98 & 1.1 & 2.0 & 0.4 & 0.6 \\
\hline 612 & Leather manufactures & 11.9 & 0.92 & 0.1 & 0.1 & 0.1 & 0.2 \\
\hline 655 & Knitted fabrics & 11.8 & 0.93 & 0.2 & 0.3 & 0.1 & 0.6 \\
\hline 778 & Electrical machinery and apparatus & 11.7 & 0.97 & 1.1 & 1.7 & 0.7 & 1.6 \\
\hline 048 & Cereal preparations & 11.7 & 0.94 & 0.2 & 0.4 & 0.1 & 0.2 \\
\hline 844 & Non-knitted undergarments & 11.6 & 0.94 & 0.2 & 0.3 & 0.8 & 0.8 \\
\hline \multirow[t]{5}{*}{772} & Electrical apparatus such as switches & 11.5 & 0.98 & 1.0 & 1.6 & 0.6 & 1.6 \\
\hline & 20 most dynamic products & 13.7 & & 10.3 & 24.2 & 9.3 & 31.2 \\
\hline & Memo item: & & & & & & \\
\hline & World exports & 8.4 & & & & & \\
\hline & Developing country exports & 11.5 & & 15.4 & 27.4 & & \\
\hline
\end{tabular}

Source: Mayer et al . (2003).

${ }^{3}$ Mayer et al. (2002: Appendix 2) provide a detailed explanation of how the measures were calculated. 
most dynamic products in world exports. Most of these products fall into four groups, namely (i) electrical and electric goods (SITC 75-77) including parts and components for such goods, (ii) textiles, and labour-intensive manufactures, in particular clothing (SITC 61, 65, and 84), (iii) finished products from industries which require high R\&D expenditures and are characterized by high technological complexity (SITC 5; 7 less 75-77; 87), and (iv) primary commodities, namely non-alcoholic beverages and cereals.

The fastest growing category of products, electronic and electrical goods, also accounts for a sizeable share in both world and developing country exports. The three fastest growing product groups in the category (transistors and semiconductors; computers; and parts of computers and office machines) alone increased their share in world exports almost four times, from 2.6 per cent in 1980 to 9.9 per cent in 2000, and their share in developing country exports rose about eight times, from 2.4 per cent in 1980 to 16.8 per cent in 2000 . Taken together, the share in world exports of the eight groups of electronic and electrical products included in Table 1 more than doubled to reach 17.5 per cent in 2000, and the share of these eight product groups in developing county exports rose more than four times, from about 6 per cent in 1980 to almost 25 per cent in 2000. By contrast, the share in world exports of the dynamic primary commodities is small, which suggests that their strong growth over the past two decades has been due, at least partly, to the fact that they started from a low base. Moreover, strong growth in the export value of primary commodities often reflects specific developments in one or a small number of exporting countries.

To overcome the difficulties in identifying export dynamism on the basis of a single measure, a composite measure is constructed which tries to incorporate individual measures in a meaningful way. Table 2 lists the 20 most dynamic products identified on the basis of a combined measure that may be called a comprehensive index of export dynamism; it includes the rate of growth in export value during 1980-2000, the volatility of this growth rate, the rate of growth in export value during 1996-2000, and the average share of a product in total world exports during $1980-2000 .^{4}$

The results give support to those based on the single measure of export dynamism referring to the period 1980-2000 (Table 1): the top four products are electrical and electronic goods (including parts and components for such goods), and eight out

\footnotetext{
${ }^{4}$ Factor analysis was used to derive the weights of these four measures in the comprehensive index. For details, see Mayer et al. (2002: Appendix 2).
} 
of the top 20 products are finished goods of high technological complexity. Again similarly to the results on the single measure of export dynamism during the period 1980-2000, several product groups from the textiles and clothing industry are among the most dynamic ones, occupying the ranks 12, 24, 27, 29 and 30. By contrast, on the composite measure no primary commodity ranks among the 20 most dynamic products.

\section{Table 2}

Shares of main exporters, developed and developing countries in world non-fuel exports of the 20 most dynamic products (ranked by index of export dynamism, $1980-2000$ ), 2000 (per cent)

\begin{tabular}{|c|c|c|c|c|}
\hline $\begin{array}{l}\text { SITC } \\
\text { code }\end{array}$ & Product group & $\begin{array}{c}\text { Share of } \\
\text { developed } \\
\text { countries }\end{array}$ & $\begin{array}{l}\text { Share of } \\
\text { developing } \\
\text { countries }\end{array}$ & $\begin{array}{l}\text { Main exporting countries } \\
\text { (shares) }\end{array}$ \\
\hline 776 & Transistors and semiconductors & 52 & 48 & $\begin{array}{l}\text { United States (17), Japan (15), Singapore (12) } \\
\text { Rep. of Korea (9), Taiwan Prov. (8), Malaysia (7) }\end{array}$ \\
\hline 752 & Computers and units thereof & 56 & 43 & $\begin{array}{l}\text { United States (13), Singapore (10), Taiwan Prov. (9) } \\
\text { Netherlands (8), Japan (8), United Kingdom (7) }\end{array}$ \\
\hline 759 & Parts of computers and office machines & 52 & 46 & $\begin{array}{l}\text { United States (14), Japan (11), Malaysia (9) } \\
\text { Taiwan Prov. (9), Singapore (7), Rep. of Korea (7) }\end{array}$ \\
\hline 764 & Telecom equipment, and parts & 70 & 29 & $\begin{array}{l}\text { United States (12), United Kingdom (8), Japan (8) } \\
\text { Germany (7), China (6), France (6) }\end{array}$ \\
\hline 871 & Optical instruments & 74 & 25 & $\begin{array}{l}\text { Japan (27), United States (20), Taiwan Prov. (9) } \\
\text { Canada (8), Germany (7), China (6) }\end{array}$ \\
\hline 541 & Medicinal and pharmaceutical products & 91 & 8 & $\begin{array}{l}\text { Germany (12), United States (12), } \\
\text { United Kingdom (10), Switzerland (10), France (10) }\end{array}$ \\
\hline 772 & Electrical apparatus, switches etc & 67 & 30 & $\begin{array}{l}\text { United States (15), Japan (15), Germany (12) } \\
\text { Taiwan Prov. (6), France (6), Mexico (6) }\end{array}$ \\
\hline 778 & Electrical machinery and apparatus & 70 & 27 & $\begin{array}{l}\text { Japan (21), United States (13), Germany (10) } \\
\text { Mexico (7), China (6), United Kingdom (6) }\end{array}$ \\
\hline 893 & Plastic materials & 72 & 26 & $\begin{array}{l}\text { United States (16), Germany (12), China (8) } \\
\text { Italy (6), France (6), Canada (5) }\end{array}$ \\
\hline 771 & Electric power machinery & 55 & 42 & $\begin{array}{l}\text { China (11), United States (11), Japan (9) } \\
\text { Germany (8), Mexico (8), Taiwan Prov. (7) }\end{array}$ \\
\hline 714 & Non-electric engines and motors & 95 & 4 & $\begin{array}{l}\text { United States (31), United Kingdom (20), } \\
\text { Germany (11), France (10), Canada (6) }\end{array}$ \\
\hline 846 & Knitted undergarments & 35 & 61 & $\begin{array}{l}\text { China (14), United States 89), Turkey (6) } \\
\text { Mexico (5), Italy (5), India (4) }\end{array}$ \\
\hline 781 & Passenger motor cars & 86 & 11 & $\begin{array}{l}\text { Germany (20), Japan (19), Canada (12) } \\
\text { France (6), Spain (6), Belgium (5) }\end{array}$ \\
\hline 872 & Medical instruments and appliances & 83 & 16 & $\begin{array}{l}\text { United States (26), Germany (11), Netherlands 86) } \\
\text { Japan (6), Mexico (5), Ireland (5) }\end{array}$ \\
\hline 773 & Electricity distributing equipment & 54 & 38 & $\begin{array}{l}\text { Mexico (18), United States (14), Germany (8) } \\
\text { Japan (6), China (5), France (4) }\end{array}$ \\
\hline 821 & Furniture and parts thereof & 64 & 28 & $\begin{array}{l}\text { Italy (14), United States (8), Germany (8) } \\
\text { Canada (8), China (7), Mexico (5) }\end{array}$ \\
\hline 515 & Organo-inorganic \& heterocyclic compounds & 90 & 8 & $\begin{array}{l}\text { Ireland (22), Germany (12), United States (10) } \\
\text { France (10), United Kingdom (9), Japan (7) }\end{array}$ \\
\hline 553 & Perfumery and cosmetics & 86 & 12 & $\begin{array}{l}\text { France (25), United States (12), } \\
\text { United Kingdom (10), Germany (10), Italy (6) }\end{array}$ \\
\hline 514 & Nitrogen-function compounds & 88 & 11 & $\begin{array}{l}\text { Ireland (24), United States (12), Germany(8) } \\
\text { Belgium (8), Japan (7), Switzerland (6) }\end{array}$ \\
\hline 898 & Musical instruments and records & 73 & 25 & $\begin{array}{l}\text { United States (16), Ireland (12), Japan (11) } \\
\text { Singapore (7), Gemany (7), Netherlands (6) }\end{array}$ \\
\hline
\end{tabular}

Source: See Table 1.

Note: See UNCTAD, Handbook of Statistics, table 4.4 for the main exporters of these products within the group of developing countries. 
Table 2 also identifies the share of developed and developing countries taken as groups, as well as that of the main individual exporters, in total world exports of the 20 most dynamic products in 2000. Although developing countries as a whole appear to have become major exporters in markets for many dynamic products, it is only in knitted undergarments (SITC 846) that the share of developing countries in world exports exceeds that of developed countries. Developed countries account for almost 90 per cent of the total export value in the eight products that require high $R \& D$ expenditures. In this category, only in optical instruments and apparatus do developing countries account for about 25 per cent of the total export value. In comparison, the share of developing countries in the total export value of part and components for electrical and electronic goods exceeds 40 per cent, while for telecommunications equipment and parts (SITC 764) and electric apparatus and switches (SITC 772) it is about 30 per cent of the total value.

\section{Dynamic Products in Exports and Multilateral Trade Liberalization}

Several factors account for the above result that the value of manufactured exports grew faster than that of primary products and that, within the group of manufactures, products from the electronics industry have registered particularly rapid export growth. Differences in the income elasticity of demand across different products can be expected to govern differences in the rate of export growth between broad product categories. For example, the comparatively low income elasticity of demand for most agricultural products is likely to have played a major role in the steady decline in the share of agriculture in developing country merchandise exports. However, ranking specific products according to their export-market dynamism during the period 1980-2000 (Table 1) suggests that factors in addition to the income elasticity of demand have influenced the export performance of specific products. While product-specific estimates of the income elasticity of demand are not available, it is difficult to imagine that goods such as parts and equipment of automatic data processing machines and undergarments are among the products with the highest income elasticity of demand. Productspecific differences in market access liberalization and the growing importance of international production networks are two additional factors that are likely to be key determinants of product-specific differences in export dynamism. This section focuses on trade liberalization within the multilateral trading system, while the 
next section addresses international production networks.

\section{A. Product-specific differences in multilateral trade liberalization ${ }^{5}$}

Differences in the speed of market access liberalization can have a significant impact on the expansion of world trade in different products. Such differences are not likely to occur when tariffs govern market access conditions and when changes in market access conditions are the result of a formula approach in multinational trade negotiations that reduce tariffs equally across different products. By contrast, such differences can occur when (i) changes in market access conditions concentrate on non-tariff measures (NTMs) applied selectively to different products and/or suppliers; (ii) market access is liberalized in different degrees and speeds for different products; or (iii) selective and targeted contingent policy measures such as tariff rate quotas or anti-dumping actions gain importance in commercial policy. Given that all these features were prominent in the evolution of the world trading system during the period 1980-2000, changes in market access conditions can go a long way in explaining why world trade in different products has expanded at significantly different rates.

The persistent and, in some instances, growing resort to NTMs by developed country was an important feature of the period between the completion of the Tokyo Round (1979) and the completion of the Uruguay Round negotiations (1994). Voluntary export restraints (VERs), in particular, were increasingly applied to trade in steel, automobiles and consumer electronics. The growing number of NTMs, especially against unsophisticated manufactures, reinforced the prevailing patterns of market access that favoured primary commodities and high-tech products over middle-ground products, which tend to gain importance in the early stages of industrialization. This structure of controls remained roughly unchanged throughout the $1980 \mathrm{~s}^{6}$ and the little change that occurred served to reinforce, rather than weaken, the bias against middle-ground products. In response to this development, during their peak development years the more advanced Asian developing countries shifted their exports into machinery and transport equipment (that is, products that faced lower tariffs and non-tariff measures). Others shifted to production and exports of products for which they faced fewer market access barriers than other

\footnotetext{
${ }^{5}$ An earlier version of this section served as a background note for UNCTAD (2002, Chapter 3).

${ }^{6}$ However, there were major increases in both NTB frequency and coverage ratios over the 1966-1986 period. Food products recorded the highest overall 1966-1986 increase in the frequency index, while among manufactured products, textiles and clothing, ferrous metals, and transport equipment were the most affected products (Laird and Yeats 1990).
} 
countries, rather than shifting to products that enjoyed better overall market access. For example, some countries with unfilled quotas under the Multi-Fibre Arrangement (MFA) increased their exports of clothing (Page 1994).

As a result of the Uruguay Round agreements, changes in the conditions of market access have varied for different products as well as for different importing countries. ${ }^{7}$ In general, barriers to trade in industrial products have been lowered more than those in agricultural products, and little has been achieved in terms of reducing trade-affecting subsidies in agriculture, particularly in the European Union (EU).

The major objective of the Uruguay Round Agreement on Agriculture was to establish a tariffs-only regime, in order to move away from a regime characterized by a large number of NTMs that were non-transparent in both their application and effects. However, the introduction of tariff rate quotas (TRQs) is one specific feature of the tariffication process in agriculture. ${ }^{8}$ TRQs have been introduced to allow minimum access where there were no significant imports before the tariffication process, or to maintain current access levels where the tariffication would otherwise have reduced access. TRQs allow a certain quantity of imports to enter a market under a specific ('in-quota') tariff and then apply a higher ('out-ofquota') tariff to imports above the quota. The difference between the two tariff rates is frequently large: in those OECD countries that apply TRQs, in-quota rates on agricultural products average 36 per cent, while out-of-quota rates average 120 per cent. Most TRQs are concentrated in a few products, mainly fruits and vegetables, followed in importance by meat, cereals, dairy products and oilseeds.

The sizeable reduction in the use of NTMs in the areas where these measures predominated has been another important outcome of the Uruguay Round. However, the phasing out period for existing NTMs differed significantly for different products: NTMs in agriculture - affecting mostly temperate zone food products (particularly grains and dairy products) and exported mainly by developed countries were to be phased out almost immediately, while those on textiles and clothing were given a transition period of 10 years, and VERs four years (Low and Yeats 1995). These imbalances have been reinforced by the unequal incidence of

\footnotetext{
${ }^{7}$ For a detailed account see World Trade Organisation (2001).

${ }^{8}$ The rules of tariffication also allowed for significant increases in tariffs, so they remain high even after the agreed reductions have been implemented. Moreover, only limited progress has been made in reducing domestic support to agriculture and trade-distorting export subsidies.
} 
VERs both across exporting countries and products. For example, as of 1992, of the 79 VERs outside agriculture and textiles and clothing, 69 involved Japan and Korea as exporters, and they applied mainly to motor vehicles and consumer electronics (Finger and Schuknecht 1999).

The failure of the Uruguay Round to impose strong limitations on the use of anti-dumping practices may be one reason why they have become the most popular contingency protection actions employed by both developed and developing countries over the past few years. During the period 1995 - 2000, antidumping investigations increased rapidly, exceeding 1800 cases, and most of the investigations were initiated against developing countries (IMF and World Bank 2002: 15). Producers of base metals (principally steel), chemicals, machinery and electrical equipment, and plastics frequently resorted to the use of anti-dumping actions (Miranda et al. 1998).

It is difficult to make a precise assessment of the impact of changes in market access conditions on the expansion of trade in different products. While most measures are the outcome of multilateral trade negotiations and are, hence, applied globally, some of the most restrictive measures, such as VERs and anti-dumping, are applied on a bilateral basis, sometimes with effects that work in opposite directions. Indeed, the prohibition of VERs in the electronics sector has coincided with increased resort to anti-dumping. In some cases, increased resort to restrictions was a response to rapidly expanding market penetration of imports, while in others liberalization provided the impetus for such expansion.

Nonetheless, regarding broad product categories, available evidence suggests that agriculture and textiles and clothing are not only the sectors for which market access conditions continue to be more restricted but also the sectors for which comparatively little and slow liberalization has been achieved. Agricultural subsidies, particularly in the EU, have been largely responsible for restricting growth of exports of a number of agricultural commodities from developing countries. Moreover, the structure of TRQs has made market access particularly restrictive for agricultural products that have a comparatively high income elasticity of demand. These two factors have certainly inhibited the expansion of world trade in agricultural products compared to manufactures. In manufacturing, apart from the textiles and clothing sectors, differences in the evolution of market access conditions are not large enough to explain the differences in the pace of expansion of trade in these products. 


\section{B. Dynamic products in exports and improved market access: four country- case studies}

The preceding section addressed evidence on product-specific differences in multilateral trade liberalization at the aggregate level of world trade. This may mask country-specific differences that could have a strong impact on export dynamism. As a matter of fact, mercantilist assessments of the outcome of the Uruguay Round suggest that the dollar value of received and given tariff concessions differ vastly across different countries. For example, Finger et al. (1999: 22) show that the dollar value of tariff concessions received by the Republic of Korea is more than double that received by Brazil, more than six times that received by India and more than one hundred times that received by Mexico. However, a comparison with the dollar value of tariff concessions given by these countries suggests that India and the Republic of Korea were net losers in reciprocal tariff concessions, while Brazil and Mexico were net gainers. The precise outcome of such mercantilist assessments surely depends on the method chosen and the assumptions made. However, they suggest that the outcome of the tariff negotiations during the Uruguay Round had a different impact on the export structure of different countries.

This section looks at the correlation between product-specific tariff concessions received by the above four countries and product-specific dynamism in their exports. Comparing for each of these four countries the 20 products (at the 3-digit SITC level) that grew most rapidly in their exports during the period 1995-2000 with the 20 products that experienced the greatest absolute decrease in effectively applied tariffs in world imports from these countries (Table 3) suggests that there is no correlation between a country's product-specific export growth and the productspecific decline in tariff barriers on world markets. For India, the Republic of Korea and Brazil, only two of the 20 most dynamic products are also among the 20 products that experienced the greatest decrease in tariff barriers, while for Mexico this is the case for only product. The rank correlation coefficient for all the products for which tariff data are available is extremely low for all the four countries.

A combination of several different reasons is likely to account for the finding that factors other than those associated with product-specific tariff concessions have determined product-specific export dynamism in the four countries. First, sectoral patterns of the decline in tariff barriers do not closely match the countries' 
export interests. Looking at resource endowments ${ }^{9}$ suggests that the comparative advantage of the Republic of Korea broadly lies in skill-intensive manufactures and that of India in labour-intensive manufactures. However, there are only very few skill-intensive manufactures among the products for which the Republic of Korea experienced the greatest decline in tariff barriers; in the case of India, the same holds for labour-intensive manufactures. By contrast, Table 3 suggests that tariff barriers for products in the clothing sector fell particularly strongly for the other two countries, while Brazil would not appear to have a comparative advantage in labour-intensive manufactures. This reflects the more general characteristic of the current trading system, namely that protection remains especially strong in products of particular interest to developing countries.

Second, tariff reductions give an incomplete picture of the actual development of market access conditions, because contingent protection, which goes beyond statutory protection in the form of tariffs and quotas, has become increasingly common in recent years. For example, since 1995 over 1800 anti-dumping investigations have been initiated, of which 1086 affected developing countries (IMF and World Bank 2002: 15). Contingent protection actions are often taken in response to specific events such as import surges. Technical barriers are another form of non-tariff barriers to trade that have become a key concern regarding market access. It has been reported, for example, that developing country trade officials view sanitary and phyto-sanitary standards and other technical requirements as a greater constraint on their ability to export than tariffs and quantitative restrictions (IMF and World Bank 2002: 16). Given that contingent protection actions and technical barriers are typically taken on a selective basis, they constitute powerful barriers to product-specific export dynamism.

Finally, forces associated with the dynamics of international production sharing or bilateral trade liberalization that have often occurred in the context of regional integration may have been predominant, particularly for export development in Brazil and Mexico.

\section{International production networks and market access}

Improved market access combined with the decline in communication and transport costs have greatly reduced the cost of trade in intermediate inputs and

${ }^{9}$ For evidence see, for example, Wood and Mayer (2001). 
Table 3

Dynamic exports and tariff declines, selected developing countries, 1995-2000

\begin{tabular}{|c|c|c|c|c|}
\hline \multirow[b]{2}{*}{ Rank } & \multicolumn{4}{|c|}{ Republic of Korea } \\
\hline & \multicolumn{2}{|r|}{ Most dynamic exports products } & \multicolumn{2}{|r|}{$\begin{array}{l}\text { Products with greatest decrease in } \\
\text { tariff barriers on the world market }\end{array}$} \\
\hline 1 & 246 & Pulpwood & 634 & Veneers and plywood \\
\hline 2 & 012 & Meat dried, etc & 045 & Unmilled cereals \\
\hline 3 & 289 & Waste of prec metal ores & 022 & Milk and cream \\
\hline 4 & 759 & Parts of computers \& office machines & 001 & Live animals chiefly for food \\
\hline 5 & 686 & Zinc & 025 & Eggs, yolks, fresh, prsrvd \\
\hline 6 & 584 & Cellulose, derivatives, etc & 042 & Rice \\
\hline 7 & 718 & Other power generating machinery & 047 & Other cereal meals and flours \\
\hline 8 & 245 & Fuel wood and charcoal & 264 & Jute and other textile bast fibres \\
\hline 9 & 711 & Steam boilers and auxil parts & 058 & Fruit, preserved \& prepared \\
\hline 10 & 265 & Vegetb fibre, exc cotton, jute & 951 & Armoured fighting vehicles etc \\
\hline 11 & 041 & Wheat etc, unmilled & 072 & Cocoa \\
\hline 12 & 871 & Optical instruments & 711 & Steam boilers and auxil parts \\
\hline 13 & 664 & Glass & 591 & Disinfectants etc \\
\hline 14 & 045 & Unmilled cereals & 121 & Unmanufactured tobacco \\
\hline 15 & 774 & Electro-medical equip & 872 & Medical instruments and appliances \\
\hline 16 & 014 & Meat prepd etc & 851 & Footwear \\
\hline 17 & 072 & Cocoa & 261 & Silk \\
\hline 18 & 671 & Pig iron, etc & 233 & Synthetic rubber \\
\hline 19 & 269 & Waste of textile fabrics & 782 & Motor vehicles for transport \\
\hline \multirow[t]{3}{*}{20} & 512 & Alcohols, phenols, etc & 057 & Fruit and nuts \\
\hline & Ran & k correlation coefficient: 0.10 & & \\
\hline & \multicolumn{4}{|c|}{ India } \\
\hline 1 & 012 & Meat dried, salted, smoked & 633 & Cork manufactures \\
\hline 2 & 793 & Ships, boats, etc & 042 & Rice \\
\hline 3 & 681 & Silver, platinum, etc & 111 & Non-alcoholic beverages \\
\hline 4 & 633 & Cork manufactures & $\begin{array}{l}011 \\
883\end{array}$ & $\begin{array}{l}\text { Fresh meat and edible meat offals } \\
\text { Cinematograph film, exposed and }\end{array}$ \\
\hline 5 & 411 & Animal oils and fats & deve & loped, negative or positive \\
\hline 6 & 245 & Fuel wood nes, charcoal & 664 & Glass \\
\hline 7 & 774 & Electro-medical, xray equip & 023 & Butter \\
\hline 8 & 265 & Vegetb fibre, exc cotton, jute & 691 & Iron, steel and aluminium structures \\
\hline 9 & 882 & Photogr and cinema supplies & 532 & Dyeing and tanning extracts \\
\hline 10 & 288 & Non-ferrous metal scrap nes & 783 & Road motor vehicles, n.e.s. \\
\hline 11 & 792 & Aircraft, etc & 562 & Manufactured fertilizers \\
\hline 12 & 656 & Lace, ribbon, tulle, etc & 621 & Rubber materials \\
\hline 13 & 873 & Meters and counters nes & 676 & Rails \& railway track construction mat \\
\hline 14 & 264 & Jute, other textile bast fibres & 223 & Oil-seeds and oleaginous fruit \\
\hline 15 & 289 & Prec metal ores, waste nes & 676 & Rails \& track construction material \\
\hline 16 & 024 & Cheese and curd & 081 & Feeding stuff for animals \\
\hline 17 & 598 & Miscel chemical prdts nes & 098 & Edible products and preparations \\
\hline 18 & 023 & Butter & 761 & Television receivers \\
\hline 19 & 516 & Other organic chemicals & 641 & Paper and paperboard \\
\hline \multirow[t]{2}{*}{20} & 821 & Furniture and parts thereof & 689 & Miscell non-ferrous base metals \\
\hline & Ran & k correlation coefficient: -0.01 & & \\
\hline
\end{tabular}

Table 3 continues 
Table 3 (continued)

Dynamic exports and tariff declines, selected developing countries, $1995-2000$

\begin{tabular}{|c|c|c|c|c|}
\hline \multirow[b]{2}{*}{ Rank } & \multicolumn{4}{|c|}{ Brazil } \\
\hline & & Most dynamic exports products & & $\begin{array}{l}\text { Products with greatest decrease in } \\
\text { tariff barriers on the world market }\end{array}$ \\
\hline 1 & 761 & Television receivers & 269 & Old clothing and rags \\
\hline 2 & 041 & Wheat etc, unmilled & 058 & Fruit, preserved \& prepared \\
\hline 3 & 232 & Natural rubber, gums & 274 & Sulphur, unroastd iron pyrites \\
\hline 4 & 524 & Radioactive etc materials & 025 & Eggs, yolks, fresh, prsrvd \\
\hline 5 & 273 & Stone, sand and gravel & 791 & Railway vehicles \& equipment \\
\hline 6 & 764 & Telecom equip, parts, acces & 046 & Meal, flour of wheat and meslin \\
\hline 7 & 792 & Aircraft, etc & 512 & Alcohols, phenols, phenol-alcohols \\
\hline 8 & 274 & Sulphur, unroastd iron pyrites & 846 & Undergarments, knitted or crocheted \\
\hline 9 & 763 & Sound recorders, phonographs & 847 & Clothing accessories of textile fabrics \\
\hline 10 & 246 & Pulpwood, chips, woodwaste & 842 & Outergarments, men's, of textile fabrics \\
\hline 11 & 098 & Edible products, preps nes & 845 & Knitted outergarments \\
\hline 12 & 288 & Non-ferrous metal scrap nes & 014 & Prep. meat and edible meat offals \\
\hline 13 & 245 & Fuel wood nes, charcoal & 261 & Silk \\
\hline 14 & 289 & Prec metal ores, waste nes & 621 & Rubber materials \\
\hline 15 & 712 & Steam engines, turbines & 678 & Iron or steel tubes, pipes and fittings \\
\hline 16 & 871 & Optical instruments & 845 & Knitted outergarments \\
\hline 17 & 781 & Passengr motor vehicl, exc bus & 074 & Tea and maté \\
\hline 18 & 941 & Zoo animals, pets, etc & 677 & Iron or steel wire \\
\hline 19 & 025 & Eggs, yolks, fresh, prsrvd & 775 & Household type equipment \\
\hline \multirow[t]{3}{*}{20} & 271 & Fertilizers, crude & 045 & Unmilled cereals \\
\hline & Ranl & k correlation coefficient: -0.08 & & \\
\hline & \multicolumn{4}{|c|}{ Mexico } \\
\hline 1 & 281 & Iron ore and concentrates & 782 & Motor vehicles for transpor \\
\hline 2 & 783 & Road motor vehicles nes & 423 & Fixed vegetable oils \\
\hline 3 & 791 & Railway vehicles & 654 & Woven textile fabrics \\
\hline 4 & 873 & Meters and counters nes & 655 & Knitted or crocheted fabrics \\
\hline 5 & 264 & Jute, other textile bast fibres & 653 & Fabrics, woven, of man-made fibres \\
\hline 6 & 712 & Steam engines, turbines & 844 & Undergarments of textile fabrics \\
\hline 7 & 633 & Cork manufactures & 012 & Meat and edible meat offals, salted etc. \\
\hline 8 & 277 & Natural abrasives nes & 651 & Textile yarn \\
\hline 9 & 244 & Cork, natural, raw, waste & 034 & Fish, fresh, chilled or frozen \\
\hline 10 & 024 & Cheese and curd & 843 & Textile outergarments, women's \\
\hline 11 & 774 & Electro-medical, xray equip & 851 & Footwear \\
\hline 12 & 628 & Rubber articles nes & 658 & Made-up textile articles \\
\hline 13 & 022 & Milk and cream & 091 & Margarine and shortening \\
\hline 14 & 881 & Photogr apparatus, equip nes & 831 & Travel goods, etc \\
\hline 15 & 691 & Structures and parts nes & 783 & Road motor vehicles, n.e.s. \\
\hline 16 & 745 & Non-electr machy, tools nes & 047 & Other cereal meals and flours \\
\hline 17 & 847 & Textile clothing accessories nes & 058 & Fruit, preserved and prepared \\
\hline 18 & 014 & Meat prepd, prsrvd nes, etc & 842 & Textile outergarments, men's \\
\hline 19 & 752 & Automatic data processing equip & 111 & Non-alcoholic beverages, n.e.s. \\
\hline \multirow[t]{2}{*}{20} & 759 & Office, adp machy parts, access & 845 & Knitted outergarments \\
\hline & Ranl & k correlation coefficient: 0.09 & & \\
\hline
\end{tabular}

Source: Export data from COMTRADE and tariff data from WITS. 
contributed to the growing importance of international production networks in world trade. Vertical international production sharing mostly occurs in labourintensive activities and takes place between areas with low trade barriers, low transport costs and significantly different wage rates. Such activities often regard production processes that are at a relatively low level of technology (such as in clothing), but they can also be labour-intensive parts of generally technologically complex production processes (such as in the electronics sector or in parts of the automotive industry). Labour-intensive production processes are spread over production sites located in different countries if doing so allows producers to take advantage of differences in technologies and factor prices among countries and, thereby, to reduce costs.

The growing importance of international production networks has changed the pattern of world trade in various ways. The rapid rise of vertical international production sharing has been reflected in the strong increase in trade in parts and components, particularly in parts and accessories of motor vehicles, parts of office and automatic data processing machines, telecommunications equipment, electric circuit equipment, and semiconductors (Yeats 2001; Ng and Yeats 2001). Network goods travel across several locations before reaching final consumers and the total value of trade recorded in such products exceeds value added by a considerable margin.

Whether tariff reductions stimulate or deter the development of international production sharing depends on where tariffs are imposed and whether they affect final or intermediate goods. Even relatively low tariff rates on intermediate inputs can have a significant impact on trade costs and hence strongly hamper the development of international production networks because goods often cross borders several times in the course of production. On the other hand, tariffs on final goods that can be produced with a fragmented technology can stimulate fragmentation if the tariff raises its price above the cost of first importing the intermediate input and then producing the final good domestically (Deardorff 2001).

This section provides some empirical evidence on the impact of tariff barriers on vertical international production looking, first, at the electronics and automotive industries where vertical international production networks are typically composed of large multinational enterprises, and then at the clothing and footwear industries where groups of sometimes small and medium-sized enterprises, located in different countries and linked through international subcontracting, form global production networks. 


\section{A. International production networks and market access in the electronics and automobile industries}

Multinational enterprises have governed international production sharing in the automotive and electronics sectors. Empirical assessments of the impact of tariffs on production sharing concentrate on US-based multinationals, because of data availability. Hanson et al. (2002a) conduct a comprehensive panel data analysis on US outward investments that includes industry specific data and several investment years. Their findings suggest that higher tariff levels in host countries are significantly correlated with less production sharing but also that vertical foreign direct investment is not more sensitive to trade barriers (other than geographical distance) than are other activities of multinational enterprises. This latter finding is surprising at first glance because international production sharing typically implies back-and-forth shipments of parts and components between parent companies and affiliates so that trade barriers could be expected to have a strong impact on vertical foreign direct investment. Hanson et al. (2002a) conjecture that to the extent that countries give specific tariff reductions to foreign firms that process imported goods for exports, observed trade barriers are poor indicators of the actual trade barriers that apply to international production sharing governed by multinational companies.

Empirical evidence on the development of effectively applied tariff rates on imports of parts and components during the period 1990-2000 suggests that the average tariff level that developed and developing countries impose on imports of parts and components declined during the 1990s and in most cases was below the overall tariff rate by the end of the decade (Table 4). However, the evidence also suggests that there is wide variation both across sectors and across countries. Tariffs on parts and accessories of motor vehicles in most cases exceed tariffs on parts and components in the electronics sector, while within the electronics sector the tariff level applied on transistors and semiconductors and on parts of computers and office machines are in most cases lower than that on other electronics parts and components. Tariff dispersion within countries is high in Mexico even between different parts of the electronics sector, while tariff dispersion in China and Malaysia is most notable between the electronics and the automotive sectors. The other countries in the Table have a less distinct pattern of tariff dispersion.

Perhaps most importantly, the evidence also suggests that effectively applied tariffs on imports of parts and components are comparatively high in China and Mexico, that is, two countries that have been among the most important recipients 
Table 4

Effectively applied tariff rates on imports of parts and components, 1990-2000

\begin{tabular}{|c|c|c|c|c|c|c|c|}
\hline \multirow[t]{2}{*}{ Country } & \multirow[t]{2}{*}{ Year } & \multicolumn{4}{|c|}{ Electronics industry } & \multirow{2}{*}{$\begin{array}{c}\begin{array}{c}\text { Automotive } \\
\text { industry }\end{array} \\
\text { Parts and } \\
\text { accessories } \\
\text { of motor } \\
\text { vehicles } \\
\text { (SITC 784) }\end{array}$} & \multirow{2}{*}{$\begin{array}{c}\text { Memo item: } \\
\begin{array}{c}\text { All } \\
\text { manufactures }\end{array}\end{array}$} \\
\hline & & $\begin{array}{l}\text { Parts of } \\
\text { computers } \\
\text { and office } \\
\text { machines } \\
\text { (SITC 759) }\end{array}$ & $\begin{array}{l}\text { Telecomm. } \\
\text { equipment } \\
\text { and parts } \\
\text { (SITC 764) }\end{array}$ & $\begin{array}{l}\text { Electical } \\
\text { apparatus } \\
\text { such as } \\
\text { switches } \\
\text { (SITC 772) }\end{array}$ & $\begin{array}{l}\text { Transistors } \\
\text { and semi- } \\
\text { conductors } \\
\text { (SITC 776) }\end{array}$ & & \\
\hline \multirow[t]{3}{*}{ Brazil } & 1990 & 20.8 & 34.3 & 31.3 & 43.0 & 35.8 & 29.3 \\
\hline & 1995 & 11.9 & 13.7 & 13.7 & 10.2 & 7.6 & 11.8 \\
\hline & 2000 & 11.0 & 16.0 & 16.5 & 9.1 & 16.8 & 15.1 \\
\hline \multirow[t]{3}{*}{ China } & 1992 & 25.0 & 34.7 & 36.2 & 20.4 & 66.8 & 36.9 \\
\hline & 1996 & 11.8 & 22.8 & 11.1 & 9.1 & 34.0 & 18.7 \\
\hline & 2000 & 9.3 & 16.2 & 10.6 & 7.9 & 27.2 & 13.7 \\
\hline \multirow[t]{3}{*}{ Hungary } & 1991 & 9.0 & 17.7 & 7.2 & 2.6 & 11.4 & 11.2 \\
\hline & 1996 & 6.8 & 12.6 & 7.5 & 6.6 & 8.6 & 8.9 \\
\hline & 2000 & n.a. & n.a. & n.a. & n.a. & n.a. & n.a. \\
\hline \multirow[t]{3}{*}{ India } & 1990 & 187.2 & 100.3 & 42.8 & 100.0 & 40.2 & 77.4 \\
\hline & 1997 & 20.6 & 26.7 & 27.4 & 16.1 & 40.0 & 23.3 \\
\hline & 2001 & 15.1 & 22.5 & 30.0 & 9.6 & 35.0 & 26.7 \\
\hline \multirow[t]{3}{*}{ Japan } & 1990 & 0.0 & 0.0 & 0.0 & 0.0 & 0.0 & 1.9 \\
\hline & 1995 & 0.0 & 0.0 & 0.0 & 0.0 & 0.0 & 1.7 \\
\hline & 2000 & 0.0 & 0.0 & 0.0 & 0.0 & 0.0 & 1.1 \\
\hline \multirow[t]{3}{*}{ Korea, Rep. } & 1990 & 13.0 & 13.1 & 13.0 & 10.3 & 13.0 & 11.5 \\
\hline & 1995 & 8.0 & 8.2 & 8.0 & 8.0 & 8.2 & 7.4 \\
\hline & 1999 & 7.9 & 8.0 & 7.9 & 2.4 & 8.0 & 6.1 \\
\hline \multirow[t]{3}{*}{ Malaysia } & 1991 & 4.3 & 24.6 & 14.8 & 3.9 & 24.8 & 10.9 \\
\hline & 1996 & 0.1 & 6.6 & 7.5 & 0.0 & 17.3 & 6.0 \\
\hline & 2000 & n.a. & n.a. & n.a. & n.a. & n.a. & n.a. \\
\hline \multirow[t]{3}{*}{ Mexico } & 1991 & 8.8 & 14.9 & 12.9 & 10.8 & n.a. & 13.3 \\
\hline & 1995 & 0.8 & 7.2 & 7.1 & 3.5 & 8.2 & 7.4 \\
\hline & 2000 & 1.3 & 16.5 & 15.5 & 4.2 & 15.8 & 14.9 \\
\hline \multirow[t]{3}{*}{ USA } & 1990 & 1.8 & 4.5 & 3.8 & 0.4 & 1.6 & 4.1 \\
\hline & 1995 & 0.1 & 2.8 & 3.0 & 0.2 & 1.2 & 2.9 \\
\hline & 2000 & 0.0 & 0.3 & 0.7 & 0.0 & 0.5 & 1.8 \\
\hline \multirow[t]{3}{*}{ EU } & 1990 & 4.2 & 5.0 & 4.9 & 15.9 & 6.1 & 6.1 \\
\hline & 1995 & 3.2 & 4.4 & 4.4 & 13.8 & 5.5 & 5.3 \\
\hline & 2000 & 0.0 & 0.6 & 0.7 & 0.2 & 2.3 & 1.8 \\
\hline
\end{tabular}

Source: WITS. 
of US foreign direct investment. This can be interpreted as supporting the summary finding of Hanson et al. (2002a), namely that low average income and/ or close geographical proximity ${ }^{10}$ to the US, in combination with low tariff levels on imports of parts and components, make host countries particularly attractive to vertical foreign direct investment. The evidence could also reflect the finding of Hanson et al. (2002b) that in addition to high host-country tariffs on imports of parts and components and high host-country wages for low-skilled workers, high host-country corporate tax rates and low incidence of export-processing zones have a significantly negative impact on imported input demand by affiliates of US-based multinationals. Taken together there is strong evidence suggesting that factors other than the decline in tariff barriers have been key determinants of the dramatic increase in world trade of parts and components in the electronics and automobile industries over the past few years.

\section{B. Preferential trading arrangements and market access in clothing and footwear}

The development of international production sharing has often been associated with the provision of preferential market access for geographically close neighbours with significantly different wage rates also in the textiles and clothing sectors. The quota restrictions under the Multi-Fibre Arrangement (MFA) have had a crucial impact on production location and trade patterns in the textile and clothing sector in particular in Asia. Other more specific arrangements centre mainly around two major countries or country groups on the import side, namely the US and the EU. The US implemented special tariff provisions already in 1964 to encourage the use of US-origin content in foreign assembly operations. Such products were returned under tariff items 806.30 and 807.00 up to 1988 , when this special tariff treatment was continued with some modification under the production-sharing provisions of Chapter 98 of the Harmonized Tariff Schedule of the US (HTS). These provisions permit a duty exemption for the value of USmade components that are returned to the US as parts of articles assembled abroad (HTS 9802.00.80) and that do not require further processing in the US, or for articles using US-origin metal (except precious metal) that are returned to the US for further processing (HTS 9802.00.60). An additional provision (HTS 9802.02.90) was created in the context of NAFTA to allow for the duty-free treatment of textile

\footnotetext{
${ }^{10} \mathrm{Geographical}$ proximity plays an especially important role when speed-to-market considerations are important such as in the electronics industry prior to the burst of the IT-bubble in the US market.
} 
and apparel products assembled in Mexico from US-formed and US-cut fabric (under the latter, value added in Mexico is free of duty in addition to the value of US-cut fabric pieces and US-made fasteners, as under 9902.00.80). ${ }^{11}$

Outward processing trade (OPT) between the EU and its trading partners ${ }^{12}$ has been concentrated in labour-intensive sectors, particularly textiles and clothing. The legislation on OPT goes back to the second extension of the MFA in 1982, when quotas for OPT were included for the first time in MFA III (1982-1986). The special treatment of textiles and clothing imports of the EU consists generally in applying customs relief within certain import limits or surveillance arrangements provided for in the bilateral textile agreements concluded by the EU with a number of supplier countries under the MFA. In practice, this usually means a combination of voluntary export restrictions (VERs), applied by the EU against the supplying country, and tariff suspension. This is a kind of preferential tariff quota on OTP re-imports but applied against suppliers on a selective basis. Access to the quota for OPT operators in the EU is subject to their meeting a number of legal and economic conditions. Countries in the Mediterranean region (especially Morocco, Tunisia and Turkey) and particularly the Baltic States and Central and Eastern European countries have been the main beneficiaries of the EUs OPTscheme. Regarding the latter, tariffs were levied only on the foreign value-added of the re-imported product until the Europe Agreements abolished all tariffs (as a first step towards these countries' membership of the EU), while re-imports from other countries continue to be subject to the quota and tariff regulations of the MFA. The quantitative importance of the EU's preferential market access provisions is reflected by the fact that in Germany more than two thirds of total trade in textile and clothing products with countries in Central and Eastern Europe are part of outward-processing operations. ${ }^{13}$

An important feature of such preferential trading agreements (PTAs) between developed and developing countries is that discrimination against non-members alters the distribution of market shares among developing countries. The impact of PTAs on trade flows depends on the degree of preferences given to members. This

\footnotetext{
${ }^{11}$ For a more detailed account, see United States International Trade Commission (1999).

${ }^{12}$ This paragraph draws on Economic Commission for Europe (1995); World Trade Organization (1998); and Graziani (2001).

${ }^{13}$ For a detailed discussion of the importance of OPT between the EU and Central European countries, see Baldone et al. (2001).
} 
can be assessed by the difference between effectively applied tariffs for members and those for non-members: the lower the effectively applied tariffs for members compared to the non-member tariffs, the higher the trade barriers to non-members. Table 5 shows that import-weighted effectively applied tariffs by the EU and the US on clothing and footwear imported from their respective partners in PTAs are lower than they are for those imported from non-member developing countries, and that they are significantly lower than MFN tariffs. This goes a long way in explaining why the shares of North African and Eastern European countries and Turkey in clothing imports of the EU have grown considerably over the past decade compared to countries that are known to have a competitive edge in these products. Even for such a strong competitor as China growth in exports lagged, on average, behind that of countries with preferential market access. It is also notable that the performance of the Eastern European countries and Turkey is much less impressive in the US market, where they do not benefit from the same preferential treatment. Similarly, by virtue of its membership of NAFTA, Mexico's performance in the US clothing market is much more impressive than that of other developing countries, and that of its own exports in the EU market. A similar pattern applies to footwear imports by the EU and the US from their respective trading partners.

Taken together the evidence suggests that, in addition to geographic proximity and significant differences in wage rates, vertical production sharing has been stimulated by discriminatory country-specific concessions for specific products under bilaterally or regionally negotiated preferential trading agreements, rather than by tariff declines that are the result of multilateral trade negotiations and apply equally to all countries.

\section{Export dynamism and further global trade liberalization}

This section looks at a hypothetical scenario and provides a quantitative assessment of the potential increase in world exports from complete trade liberalization. It uses the results from Hertel's (2000) projection (based on the GTAP model) of the impact on the volume of world trade that would follow from an across-the-board abolition of estimated 2005 agriculture protection, business and finance, and construction services protection, as well as extractive industries and 
Table 5

Clothing and footwear imports of the European Union and the United States and related import-weighted tariffs, by region, 1990-2000 (per cent)

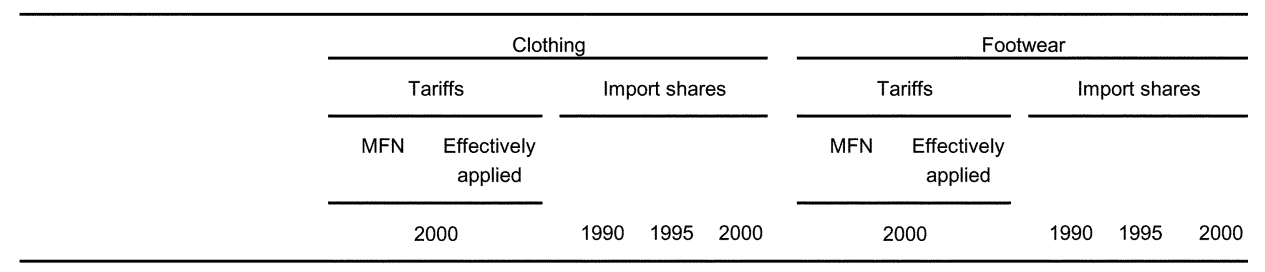

Imports of the European Union from:

Countries with preferential market access a)

North Africa Eastern Europe Turkey 12.2 $\begin{array}{llll}0.0 & 4.9 & 6.8 & 7.2 \\ 0.0 & 3.6 & 9.9 & 10.9\end{array}$ $\begin{array}{lllll}12.2 & 0.0 & 3.6 & 9.9 & 10.9\end{array}$ $\begin{array}{lllll}8.3 & 0.0 & 0.6 & 1.5 & 1.8\end{array}$ ther countries

China

India

Mexico

NIES

ASEAN-4

$\begin{array}{rrrrr}11.1 & 9.2 & 5.1 & 7.7 & 10.6 \\ 10.8 & 9.0 & 2.8 & 3.9 & 3.4 \\ 9.9 & 6.0 & 0.0 & 0.0 & 0.0 \\ 11.9 & 11.9 & 11.1 & 8.1 & 8.6 \\ 10.8 & 8.9 & 4.2 & 4.8 & 5.5\end{array}$

Imports of the United States from:

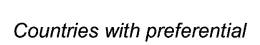

Source: Author's calculation, based on UNCTAD and World Bank, World Integrated Trade Solution database and United Nations, Department of Economic and Social Affairs, Commodity Trade Statistics database.

Note: Eastern Europe includes Bulgaria, Czech Republic (1995 and 2000), Czechoslovakia (1990), Estonia (1995 and 2000), Hungary, Latvia (1995 and 2000), Lithuania (1995 and 2000), Poland, Romania, Slovakia (1995 and 2000), and Slovenia (1995 and 2000). North Africa includes Egypt, Morocoo, and Tuninia. NIEs includes Hong Kong (China), Republic of

Korea, Singapore, and Taiwan Province. ASEAN4 includes Indonesia, Malaysia, the Philippines, and Thailand. a) For the types of PTA see WTO 2000. Trade Policy Review: European Union Vol. 1, p. 31.

manufacturing tariffs. ${ }^{14}$

The projection uses data on trade flows and trade barriers for 1995 and adopts a number of assumptions that influence the results, including perfect competition, constant returns to scale in production activities, and continuous labour market equilibrium. Nevertheless, the projection results are useful in identifying the sectors that will gain from liberalization and the order of magnitudes involved. As

\footnotetext{
${ }^{14}$ For a description of the GTAP modelling framework, see Hertel (2000).
} 
such, the projected sectoral changes in global export volume during the period 1995-2005 can be applied to calculate the change in sector-specific shares in total world exports.

According to the projections in Hertel (2000), full liberalization across all sectors boosts world trade by about 20 per cent. Three quarters of this increase is due to manufacturing tariff cuts, while most of the remainder is due to agricultural liberalization. Beverages and tobacco, dairy products, wearing apparel, and textiles account for the largest increase in trade volume on a sectoral basis (Figure 1). The average rate of protection worldwide is comparatively high in all these sectors. By contrast, for some of the agricultural products trade increases much less than might have been expected purely on the basis of average import protection. This is due to the elimination of subsidies on the production and exportation of farm products, which in particular for the EU sharply reduces predicted food exports as a result of trade liberalization. Nonetheless, the projections suggest that moving to full trade liberalization would lead to an increase in the share of agricultural products in total world trade by almost two percentage points over the period 1995-2005 and give greater weight to the textile, clothing and automotive sectors within manufactured exports (Figure 2).

Figure 2 also shows the actual sector-specific shares in world exports in 2000, that is, half way through the simulation period. A comparison between the actual shares in 1995 and 2000 and the predicted shares in 2005 has two notable features. First, the actual shares of all agricultural sectors in 2000 are far below the predicted shares in 2005, as well as sizeably below the actual shares in 1995, while this comparison shows a more mixed pattern for the other sectors. The continued existence of powerful market access barriers for agricultural products is clearly an important reason for this discrepancy. Second, the simulation predicted that the share of the electronics sector would experience the largest drop of all industrial sectors between 1995 and 2005, while the share of this sector actually experienced by far the strongest increase between 1995 and 2000. It is possible that the burst of the IT bubble in 2000 will lead to a decline in world trade in electronics products between 2000 and 2005. However, this finding also illustrates that the elasticities between a decline in tariffs and an increase in world trade that underlie standard trade models are much too low to reflect the evolution of world trade in sectors that are strongly affected by vertical international production sharing. Hence, this finding gives support to the reasoning in Yi (2003) that was discussed in the introduction. 
Figure 1. Simulated global export volume, by industrial sector, percentage change during the period 1995-2005 owing to full liberalization in 1995

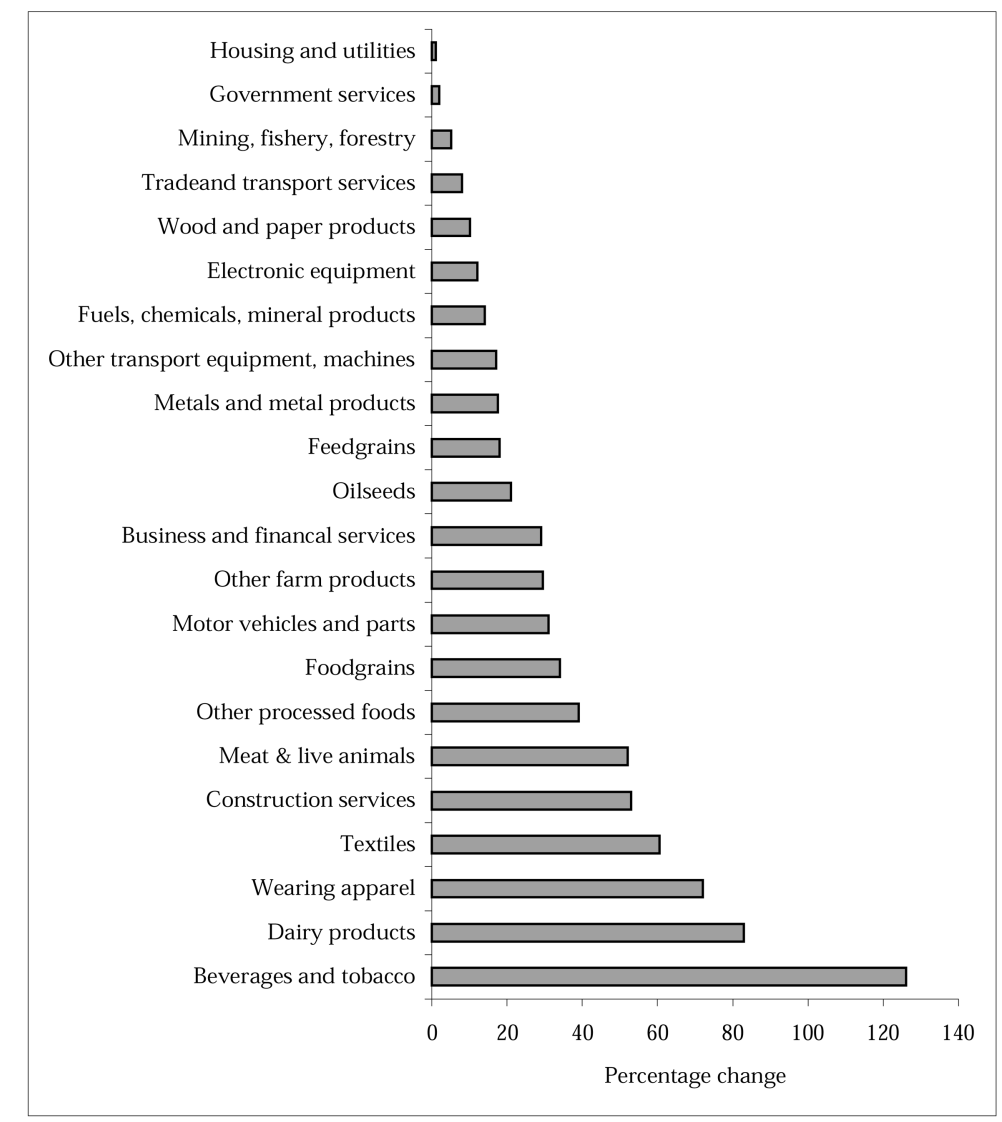

Source: Hertel (2000, p. 87).

\section{Conclusions}

Three product groups have been identified as those whose export values have grown most rapidly during the period 1980-2000: electrical and electronic goods (including parts and components for such goods), goods that require high R\&D expenditures and that are characterized by high technological complexity, and labour-intensive products in particular clothing. Various primary products have also experienced strong export value growth but they started from a low base and their growth performance has been marked by considerable volatility.

The fact that average tariffs in industrial goods have fallen steadily over the past few decades, while protection in agriculture has risen in particular since the late 
Figure 2. Actual market shares predicted market shares following full trade liberalization, by industrial sector, 1995, 2000 and 2005

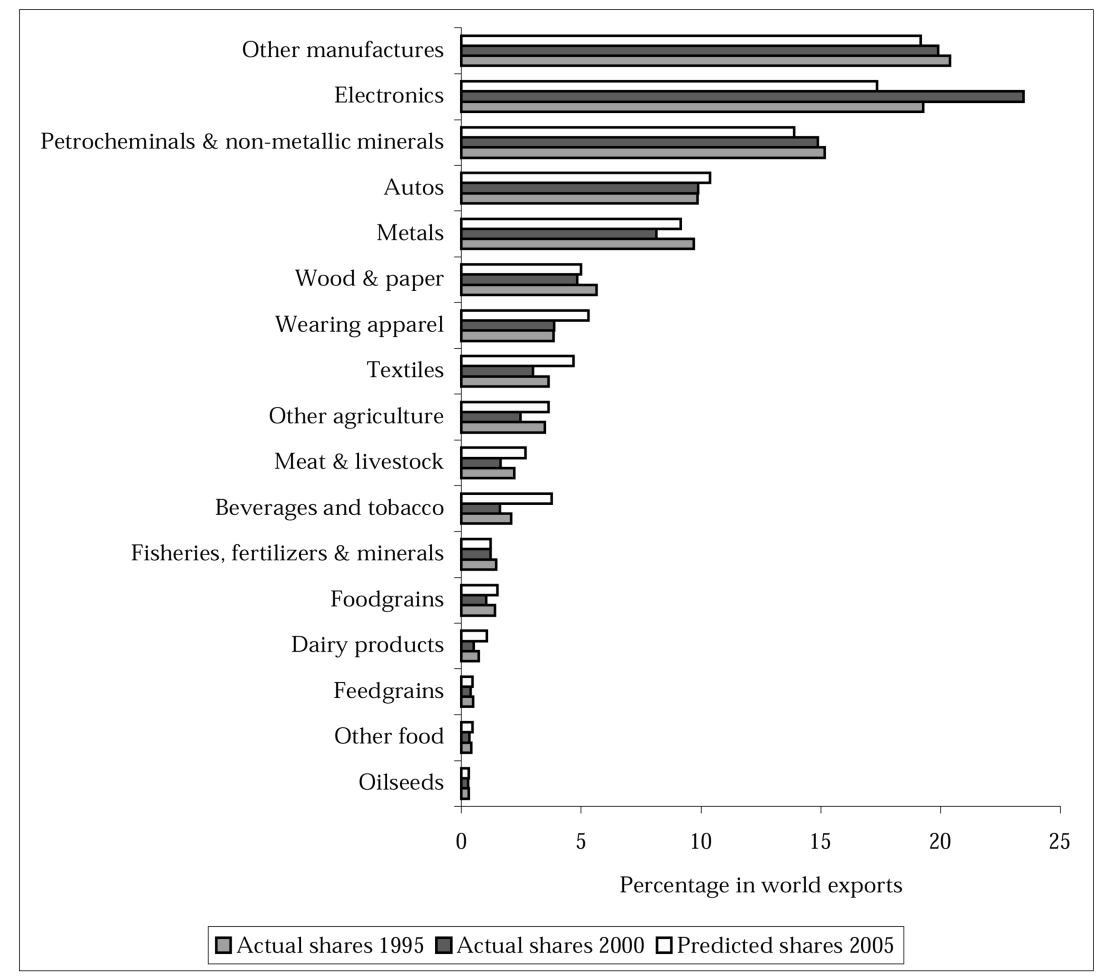

Source: Author's calculations based on data from COMTRADE and Hertel (2000).

1960s has clearly contributed to the shift in the composition of global exports, in favour of manufactures. By contrast, in manufacturing, differences in changes of market access conditions based on multilateral trade negotiations are not large enough to explain differences in the pace of expansion of trade in these products. The spread of vertical international production sharing appears to have played a key role. While it is difficult to determine the impact of tariffs on production sharing, there is evidence to suggest that, in addition to geographic proximity and significant differences in wage rates, vertical production sharing has been stimulated by discriminatory country-specific concessions for specific products under bilaterally or regionally negotiated preferential trading agreements, rather than by tariff declines that are the result of multilateral trade negotiations and apply equally to all countries.

Case study evidence indicates that there may be no correlation between productspecific tariff concessions received by Brazil, India, the Republic of Korea and 
Mexico as an outcome of the Uruguay Round agreements and product-specific dynamism in their exports between 1995 and 2000. Apart from the impact of forces associated with the dynamics of international production sharing and regional integration, the main reasons for this are likely to include the fact that contingent protection measures and technical barriers, which go beyond statutory protection in the form of tariffs and quotas, have become increasingly common in recent years and that in the current trading system protection remains particularly strong in products of particular interest to developing countries.

Projections based on a standard trade model suggest that a move towards full trade liberalization across all sectors would boost world trade by about 20 per cent and that three quarters of this increase would be due to manufacturing tariff cuts, while the effects of agricultural liberalization would account for most of the remainder. This would lead to an increase in the share of agricultural products in total world trade by almost two percentage points over the period 1995-2005. However, the simulation results are likely to be subject to a wide margin of error in particular for sectors for which vertical international production sharing plays an important role.

The paper should be seen only as a first step towards a comprehensive analysis of the determinants of sector-specific growth in world exports over the past few years. While the evidence presented on the basis of the statistical analysis is suggestive, a comprehensive analysis would probably need to be based on an econometric study relying, for example, on modified versions of the models discussed in the introduction. However, the results presented in this paper are important for this undertaking as they indicate that discriminatory country- and sector-specific tariffs may have a more important impact on differences in export growth across products than tariffs that are the outcome of multilateral trade negotiations and applied across industrial sectors, and that the impact of a decline in market access barriers on trade growth strongly differs across industrial sectors.

\section{Acknowledgements}

The author is grateful to participants of the UNU/WIDER Project Meeting for helpful comments on an earlier draft. The opinions expressed are only those of the author and do not necessarily reflect the views of UNCTAD. 


\section{References}

Baier, S. L., and J. H. Bergstrand (2001). The Growth of World Trade: Tariffs, Transport Costs, and Income Similarity. Journal of International Economics, 53: 1-27.

Baldone, S., F. Sdogati, and L. Tajoli (2001). Patterns and Determinants of International Fragmentation of Production: Evidence from Outward Processing Trade Between the EU and Central Eastern European Countries. Weltwirtschaftliches Archiv, 137: 80104.

Deardorff, A. V. (2001). 'Fragmentation Across Cones', in S. W. Arndt, and H. Kierzkowski (eds), Fragmentation: New Production Patterns in the World Economy. Oxford: Oxford University Press.

Economic Commission for Europe (ECE) (1995). Economic Bulletin for Europe, 47. Geneva: United Nations.

Feenstra, R. (1998). Integration of Trade and Disintegration of Production in the Global Economy. Journal of Economic Perspectives, 12 (4): 31-50.

Fink, C., A. Mattoo, and I. C. Neagu (2002). Assessing the Impact of Communication Costs on International Trade. Working Paper No. 2929. Washington, DC: World Bank.

Finger, J. M., and L. Schuknecht (1999). Market Access Advances and Retreats: The Uruguay Round and Beyond. Working Paper No. 2232. Washington, DC: World Bank.

Finger, J. M., U. Reincke, and A. Castro (1999). Market Access Bargaining in the Uruguay Round: Rigid or Relaxed Reciprocity. Working Paper No. 2258. Washington, DC: World Bank.

Graziani, G. (2001). 'International Subcontracting in the Textile and Clothing Industry', in S. W. Arndt, and H. Kierzkowski (eds), Fragmentation: New Production Patterns in the World Economy. Oxford: Oxford University Press.

Hanson, G. H., R. J. Mataloni, and M. J. Slaughter (2002a). 'Expansion Strategies of US Multinational Firms', in D. Rodrik, and S. Collins (eds), Brookings Trade Forum 2001. Washington, DC: The Brookings Institution.

Hanson, G. H., R. J. Mataloni, and M. J. Slaughter (2002b). Vertical Specialization in Multinational Firms. Mimeo (September).

Hertel, T. W. (2000). 'Potential Gains From Reducing Trade Barriers in Manufacturing, Services and Agriculture'. Federal Reserve Bank of St. Louis Review, 82: 77-99.

International Monetary Fund and the World Bank (2002). Market Access for Developing Country Exports - Selected Issues. Washington, DC: IMF.

Laird, S., and A. Yeats (1990). 'Trends in Nontariff Barriers of Developed Countries, 1966-1986’. Weltwirtschaftliches Archiv, 126: 299-235.

Low, P., and A. Yeats (1995). Nontariff Measures and Developing Countries: Has the Uruguay Round Leveled the Playing Field? The World Economy, 18: 51-70.

Mayer, J., A. Butkevicius, and A. Kadri (2002). 'Dynamic Products in World Exports'. 
Discussion Paper No. 159. Geneva: UNCTAD.

Mayer, J., A. Butkevicius, A. Kadri, and J. Pizarro (2003). 'Dynamic Products in World Exports'. Review of World Economics, 139: 762-795.

Miranda, J., R. A. Torres, and M. Ruiz (1998). 'The International Use of Antidumping: 1987-1997'. Journal of World Trade, 32: 571.

Ng, F., and A. Yeats (2001). 'Production Sharing in East Asia: Who Does What for Whom and Why?', in L. K. Cheng, and H. Kierzkowski (eds), Global Production and Trade in East Asia. Boston: Kluwer Academic Publishers.

Page, S. (1994). How Developing Countries Trade. The Institutional Constraints. Routledge: London and New York.

UNCTAD (2002). Trade and Development Report 2002. New York and Geneva: United Nations.

UNCTAD (various years). Handbook of Statistics. United Nations: New York and Geneva.

United States International Trade Commission (USITC) (1999). Production Sharing: The Use of US Components and Materials in Foreign Assembly Operations, 1995-1998. USITC Publication 3265, Washington, DC (December).

Wood, A., and J. Mayer (2001). 'Africa's Export Structure in a Comparative Perspective'. Cambridge Journal of Economics, 25 (3): 369-394.

World Trade Organization (1998). Trade Policy Review: European Union 1997. Geneva: WTO.

World Trade Organisation (2001). 'Market Access: Unfinished Business. Post-Uruguay Round Inventory and Issues'. Special Studies No. 6. Geneva: WTO.

Yeats, A. (2001). 'Just How Big is Global Production Sharing?', in S. W. Arndt, and H. Kierzkowski (eds), Fragmentation: New Production Patterns in the World Economy. Oxford: Oxford University Press.

Yi, K.-M. (2003). 'Can Vertical Specialisation Explain the Growth of World Trade'. Journal of Political Economy, 111 (1): 52-102. 